\title{
The Burden of Sickle Cell Disease to Parents of Sufferers in Nigeria
}

\author{
Caroline Okumdi Muoghalu \\ Medical Sociologist, Department of Sociology and Anthropology, Obafemi Awolowo University, Ile-Ife, Nigeri
}

Received: October 05, 2016; Accepted: October 28, 2016; Published: November 08, 2016

*Corresponding author: Caroline Okumdi Muoghalu, Medical Sociologist, Department of Sociology and Anthropology, Obafemi Awolowo University, Ile-Ife, Nigeria, Tel: +2348056681600; Email: omuoghal@yahoo.co.uk

\begin{abstract}
It has been established that Nigeria bears the greatest burden of sickle cell disease in the world. There are forty million carriers of the gene in the country making it a significant public health concern in Nigeria. Owing to the fact that sickle cell disease is very symptomatic and requires constant care, parents of people living with sickle cell disease suffer untold hardship in the course of taking care of them. This paper examined the burden experienced by parents of sickle cell disease in caring for them. The burden includes financial, emotional and physical stress. These objectives were examined using culture and political economy as conceptual frameworks. It was indicated that many parents with people living with sickle cell disease experience financial burden in the form of financial cost for treatment and also in the form of loss of income due to the time spent on routine day to day care for people living with the disease. Also, these parents experience emotional trauma as they feel the pain of their loved ones and anxiety over fear of losing the individual. Furthermore, it was shown that sickle cell disease is a significant stressor on the family as it brings about incessant quarrels between spouses which may lead to family break up and more heartache. The paper concluded that sickle cell disease is an all- round financial, physical and emotional stressor for parents of sufferers in Nigeria. The paper recommended that sickle cell disease sufferers should be placed on free medical care in public hospitals in order to alleviate the burden on their parents. Also, Sickle Cell Forum of Nigeria should pressurize the federal government to implement the recommendation of the National assembly- that government should subsidize the treatment cost of sickle cell disease sufferers in the country.
\end{abstract}

Key words: Sickle cell; Parents; Caregiver; Burden; Trauma and financial cost

\section{Introduction}

Confronting the problem of care for people living with sickle cell disease is becoming an enormous task and a huge social problem due to the magnitude of the problem. This ranges from the large number of people that are involved to the huge sum of money that is lost, the time lost on constant care and most importantly, the emotional trauma those patients and their parents have to pass through on a daily basis. People living with sickle cell disease are always in and out of hospital which creates physical stress, trauma, financial stress and sometimes confusion for their caregivers. The caregivers in this paper are the parents of people living with sickle cell disease in Nigeria. The parents look after the sufferers in the day to day routine care. Owing to the fact that parenting in Nigeria can include people who are not biological parents, I have chosen to limit the paper to only biological parents and they represent family in this paper. Also, I chose to focus on the parents because as has been noted [1], in Nigeria with high prevalence of sickle cell disease, parents bear most of the burden of care for patients living with sickle cell disease because of lack of national social welfare provisions. As such, parents bear the greatest burden of care and support for people living with the disease and this is why the focus of this paper is on parents caring for people living with sickle cell disease. Due to the burden of this disease, these parents experience absenteeism from work, trauma, impoverishment and stress which affect their own health and life generally.

The physical stress, financial stress and trauma all constitute the burden of caring for people living with sickle cell disease. The physical stress is the body aches, pains, fatigue, sleeplessness and sometimes burnouts experienced by parents of sufferers. The physical stress results from the daily routine care such as feeding, washing of clothes, bathing of the sick, feeding them and accompanying them to clinics that parents render to patients living with this disease. The financial stress is mainly the money spent by parents on paying for drugs, hospital bills/beds, and transportation from hospitals and money spent on extra foods and vegetables given to people living with sickle cell disease so as to beef up their general health. The parents of the sufferers have to provide for all these without any help from any government agency which constitute serious burden to them. Also, the trauma associated with the disease is enormous for parents. Trauma is used in this paper to describe the emotional stress that parents go through which include fear that the child may die at any moment which can be devastating in a culture in which having children is the main reason for marriage. Trauma also includes the regrets, the anger, strained relationships between spouses due to sickle cell disease in the family, the conflicts which usually ensues between parents of a child living with sickle cell disease.

Globally, sickle cell affects 100 million people worldwide and it is responsible for 50 percent mortality in those with the severe form of the disease [2]. It is among top ten non communicable 
diseases causing significant disability, morbidity and mortality [2]. There is presently no cure for sickle cell disease but the cost effective treatment exists for the pain and other aspects of the disease [3]. In Africa, the highest prevalence of sickle cell rate occurs between latitude 15 degrees north and 20 degrees south ranging between 10 percent and 40 percent of the population in some areas [4]. The sickle cell belt in Africa is mainly east and western Africa with Nigeria, Ghana, Cameroun, Republic of Congo, Uganda and Gabon having high prevalence of the disease [4].

In Nigeria, it was noted that sickle cell disease is a major disorder of public health importance. There are forty million people carrying the gene for sickle cell disease in the country [2]. The prevalence rate of sickle cell disease in Nigeria is 20 to 30 percent and the disease affect about 2 percent of the population [4]. Nigeria is the most sickle cell endemic country in the world and the country loses over 150,000 babies born with this serious condition every year [3]. Indeed, Nigeria has been said to bear the greatest burden of sickle cell disease in the world. Sickle cell disease also results in infant death of 100,000 representing 8 percent of infant mortality in the country [2]. This could explain why Nigeria always join the rest of the world to mark sickle cell disease on every $19^{\text {th }}$ of June. This country's great burden means that many parents are bearing the burden of the disease as there is no special healthcare programme or intervention for sufferers. It was this burden that prompted the Nigerian legislatures in June 2016 to advocate for the federal government to subsidize sickle cell patients' treatment costs [5]. It is important to note that only five percent of children with sickle cell disease live past the age of 10 years in Nigeria compared to over 96 percent surviving into adulthood in United Kingdom and United States. This is a sign that Nigeria has not given the sickle cell disease the attention that it deserves. In-spite of its magnitude and significance in Nigeria, it has not been given adequate attention by both government and researchers. This was noted [6] that despite the overwhelming health challenges caused by the sickle cell disease, there is insufficient agenda given to the disorder. The implication of the high level neglect by the Nigerian government is that parents of sufferers do not have any form of support from government and they bear the total burden of care and financial cost for the treatment of the disease which interferes heavily with the lives of the people living with it.. This high level of interference in the lives of patients also affects the lives of their parents.

Sickle cell disease is a blood disorder which is inherited from parents. It was also described [7] as an autosomal recessive genetic disease in which an individual carrier inherited one copy of the defective hemoglobin gene from each parent. In the same vein, it was described as a genetic disorder due to the presence of an abnormal form of haemoglobin in the red blood cells (S) [3]. It is a genetic blood disorder that affect the haemoglobin within the red blood cells and it results in recurrent pain and complications which interfere with many aspects of patients life; education, employment and psychosocial development [4]. When both parents are carriers, they have a one in four chance with every pregnancy of having a child with sickle cell disease [3]. Persons with AS haemoglobin are referred to as sickle cell carriers while those with SS only suffer from sickle cell disease.

There have been few studies on the burden of sickle cell disease to family members in Nigeria and these studies reported financial and social related burdens. For instance, the studies found high financial burden among families with sickle cell patients in crises, enormous time spent on the children and neglect of other family members which cause misunderstanding in the family $[1,8]$. It was also found that 87 percent of parents of children with sickle cell disease regretted having such children [9]. In this paper, these issues will be synthesized and will be further examined and the implications will be drawn.

In writing about the motivation for this paper, I see around me on a daily basis, the trauma and the high mortality associated with sickle cell disease and the problems that parents of such children go through in running around to care for people living with sickle cell disease. I have also observed that sometimes, a couple may have two or three or all their four or five children living with sickle cell disease. This gives one an idea of the magnitude of the problem. This paper therefore becomes important in the sense that the paper promises to be the window through which the trauma and impoverishment that parents who care for sickle cell sufferers is viewed and which can engender effective intervention programmes.

The aim of this paper is to examine the care-burden experienced by parents of people living with sickle cell disease in Nigeria. This includes the money they spend, the time spent in caring for them and the emotional stress that parents go through and specific tasks of caring for the sick by these parents. In doing this, Weber's definition of the situation and interpretative phenomenological approach were employed to explain the parents 'interpretation of the situation, convictions and perseverance in the continued care for people living with sickle cell disease.

\section{Conceptual Framework}

The conceptual framework is coming from the premise that culture to a great extent determines what people do in every society. Culture is that complex whole which includes knowledge, belief, art, morals, law, custom, and any other capabilities and habits acquired by man as a member of society [10]. Culture therefore determines the way a child is regarded and which influences how he/she is cared for when such a child is sick.

In the Nigerian context, a child is regarded as the ultimate wealth that any family in particular and community at large can have and any marriage that fails to produce a child is regarded as failed and the family tries to solve the problem by the man marrying a second wife or practicing serial monogamy until he begets a child. This gives one an idea of the importance of a child in the Nigerian society. When the child comes, the family cares for him/her with everything in their power- showering the child with love and care. This love and care is usually extended to blood relatives and other community members [11]. This belief system implies that in the event of any sickness or misfortune, the child 
is cared with everything the family can lay hands on with utmost commitment and compassion. This cultural platform and belief system influence how parents care for their children living with sickle cell disease. It also gives one an idea of how traumatic the illness episodes will be to such parents.

In this paper, Weber's verstehen and definition of the situation ${ }^{12}$ illuminated the path for explaining parents' experience of sickle cell disease in Nigeria. Webers verstehen and definition of the situation represent an interpretative understanding of the phenomenon in which the sociologists ability to understand social phenomenon becomes a methodological tool as it illuminated our path on how people's beliefs and motives led to particular type of behavior and action [12]. The particular type of behavior in this case is the routine care, the money, the emotional stress and time spent on caring for people with sickle cell disease. In this context, parents spend so much time, money, energy to care for loved ones living with sickle cell disease.

Verstehen implies interpretative/ empathic understanding. The parents of people living with sickle cell disease show a lot of understanding and empathy for the sufferers. In strange ways that have meanings only to them, the parents feel the pain, the anguish, the gnashing of teeth and the sufferings of sickle cell patients. It is within this context that the care and cost of care and trauma associated with sickle cell disease as experienced by parents of sufferers is located.

To weber, the basis of sociological analysis was the meaning that individuals give to the social world and their situation in it [13]. The meaning the sickle cell disease has to the parents of the sickle cell sufferers is that sickle cell is a misfortune to the family and they treat it the way misfortunes are handled in the Nigerian context- by giving it their best efforts; all ones energy, money, time in order to solve the problem. Importantly, the political economy of Nigeria plays a big role in the suffering which parents of people living with sickle cell disease go through. Owing to the political economic situation in contemporary Nigeria, many families had fallen into abject poverty including many families of people living with sickle cell disease. As such, the best efforts of many parents are not good enough due to poverty which has made it difficult for such families to meet their basic needs and to take care of people living with sickle cell disease. This is made worse by the current high rate of inflation which has reduced drastically the people's purchasing power. Furthermore, the fact that there is no effective intervention programmes to subsidize the cost of treatment and ameliorate the problems being encountered by parents of people living with sickle cell disease in Nigeria has left the care for them totally on the shoulders of their impoverished parents. The subsidy mentioned by the Nigerian members of the National Assembly has not come to fruition and it is not clear when it will be turned into action.

\section{Methodology}

In searching for data for preparation of this paper, the literatures on sickle cell disease in Nigeria were reviewed. The parameters for the data search were sickle cell disease and burden of care. . The data bases that were used in the search were books, journals, World Health Organization, Nigeria Office website and Google scholar

The key terms that were employed were sickle cell disease, financial, emotional and physical burden of sickle cell disease and the impact on parents/families. Content analysis of relevant articles and books was conducted which enhanced effective review. The analysis was conducted thematically and each objective formed a theme and the conclusion was drawn from the findings. The interpretative phenomenology approach was employed in analyzing the burden of sickle cell disease on parents of sufferers.

\section{Financial Burden for Sickle Cell Disease to Parents of Sufferers}

The cost of treatment for sickle cell disease continues to be a great burden to parents of people living with the disease. For instance, a Nigerian study found high financial burden on the families of people with sickle cell disease [1]. Especially in recent times, cost of treatment for any sickness in Nigerian hospitals has increased due to the introduction of user charges in public hospitals. In fact, an illness episode can cost a family as much as $\mathrm{N} 100,000(\$ 250)$. This is a huge amount considering that in many families in Nigeria today, it is difficult to have N20, 000. One can then imagine what $\mathrm{N} 100,000$ would mean to such families. This could explain why some families had to take loans to pay for the hospital bills of their family members living with sickle cell disease. As noted in one Nigerian study, 19.6 percent had to take loans in order to meet up with the cost of treatment [8]. In such families, basic needs will not be met and it was found by the study that 53.3 percent of their participants stated that the care for their children with sickle cell disease adversely affected the provision of their basic needs ${ }^{8}$. This has serious implications for the health of the family members and the nutrition, general health and well being of the sickle cell disease sufferers. This poor nutrition in many families with a member living with sickle cell disease when put together culminates in the poor health of Nigerians

In this paper, financial cost also includes cost of treatment and loss of income on the part of parent-caregivers. Due to the fact that sickle cell disease is highly symptomatic and that sufferers require routine care most of the time, the parents who provide such care end up not being able to fully pursue their economic activities there by losing income. For instance, it was reported that 73,3 percent of family caregivers indicated that the time spent on caring for the child made them lose income ${ }^{8}$. This loss of income has the effect of deepening the high level of poverty in many families. The problem associated with financial cost for treatment and care for people living with sickle cell disease constitutes a major stressful aspect of the management of the disease. This is especially so for poor families whose members thrive on what they are able to get from their daily work. When this daily work is disrupted by caring time for sickle cell sufferers, the income of such families dwindles and they find it difficult to feed and to get money for such consistent care and treatment. Such families usually fall into deeper level of poverty. This issue 
has exposed the nature of policy on health in Nigeria. In the health policy, there is no provision to help or subsidize the treatment cost for people living with sickle cell disease. The suffering that these families go through culminated in the national assemblymembers of the house of representative deliberating on the problem and calling on the federal government to subsidize treatment cost for people living with sickle cell disease in Nigeria [5]. Importantly, this is still at the level of deliberation. There has not been any noticeable policy or implementation strategy put in place for the realization of this laudable deliberation outcome. This lack of money also heightens the trauma associated with caring for people living with sickle cell disease.

\section{Trauma Associated With Sickle Cell Disease in the Family}

Sickle cell disease is a disease that comes with a lot of painful symptoms and by this very nature, it is always traumatic to parents and significant others. People living with sickle cell disease are always visiting the hospital due to illness and this breeds trauma and tension in the family. For instance, in a Nigerian study, 42 percent of the participants stated that in the bid to care for sickle cell disease sufferers, they neglect other family members and 14.2 percent experienced disruption in their daily interaction within the family while 12.4 percent quarrel always due to the child's illness ${ }^{8}$. It is important to note that neglecting other family members especially neglect of husbands can spell doom for any married woman in Nigeria and women are the family care givers. As such, it is likely that this 42 percent that neglect other families members are women who neglect their husbands and other children while taking care of the child with sickle cell disease. This will generate serious complaints from such husbands and no wonder the study also found frequent quarrels due to the child's illness. These quarrels no doubt breed general unhappiness and trauma in the family and in some cases, the man may walk out of the marriage leaving the woman and the child to suffer untold hardship. This is especially significant in Nigeria where many women still depend on their husbands for feeding, accommodation and healthcare bills.

All these traumatic events could explain why majority of the participants regretted having such children and cited lack of awareness, nonchalant attitude to screening test result due to love for one's partner, inadequate medical facilities for adequate genotype test in rural areas, wrong perception of sickle cell disease $^{8}$. This result is an indication that majority of parents with children living with sickle cell disease are regretting it due to the fact that it is very traumatic to be helplessly watching a loved one suffer so much pain and there is nothing one can do about it. This is especially so in Nigeria where a child is very precious and the tap root of every marriage. Importantly, this regret can result in so many things. It can bring about neglect of the child with sickle cell disease. It can also bring about a spouse abandoning the other with the child. It can also lead to depression and mental illness on the part of the parent. All these would have a multiplier effect on the wider society.

Also included in this trauma is the tension and fear that the child might die and the thought of this alone is very devastating especially for mothers. It is noteworthy that in Nigeria, most mothers' lives and marriages are heavily attached to the lives of their children. Therefore, one can imagine the level of trauma which mothers who are caregivers of their children living with sickle cell disease are passing through. Disruption of family routine and distress in the family were also reported by another Nigerian study ${ }^{5}$ which found that 57.9 percent of all caregivers experienced little or no difficulty in coping with sickle cell disease and that relatives with higher educational and occupational attainments experienced significantly less financial burden, disruption of family routine and psychological distress. Also family members of sickle cell disease experienced similar financial, family routine burdens and psychological distress scores with a similar study of cancer patient families 5 . The fact that caregivers with higher educational and occupational status experience less stress and trauma is an indication that higher level of education which brings about higher income, higher level of knowledge and higher occupational status tend to reduce the trauma and stress associated with caring for people living with sickle cell disease. It is also an indication that financial burden also breeds trauma which could explain the reason for poor families experiencing more trauma than well to do families. This could explain why 33.8 percent in a Nigerian study ${ }^{8}$ had difficulty coping with the care of their children living with sickle cell disease and 84.4 percent felt sorrowful or depressed, 31.1 percent always felt angry with themselves and with the child and 27.1 percent felt stigmatized. These feelings are signs that sickle cell disease in a family is very traumatic and can even push a caregiver to mental illness. It can also lead to people abandoning such children. In-fact, what is still sustaining many families to continue to take care of loved ones living with Sickle cell disease is the cultural belief system in Nigeria in which the family must continue to take care of a blood relative until the individual is no longer breathing. Infact in my particular culture, an adage says that monkey said that as long as her child's head is up the shoulder, she will continue to care for the child. Perhaps, it is this conviction that is sustaining many parents in caring for people living with sickle cell disease especially in these hard times of economic recession in Nigeria.

Also, the lack of awareness, nonchalant attitude to screening test result due to love for one's partner, inadequate medical facilities for adequate genotype test in rural areas, wrong perception of sickle cell disease which were cited by parents of children living with sickle cell were important significant indicators that Nigeria is not giving the problem of sickle cell disease the serious attention that it deserves. This is because; these reasons above are issues that can be handled and contained through intensive public health education in every nook and cranny of Nigeria. Public health education is the responsibility of the primary healthcare sector but primary healthcare sector is not effective in the country. Otherwise how do one begin to explain the lack of awareness on the part of the Nigerian public on an issue as serious and widespread as sickle cell disease. This constitutes a blemish on the Nigerian political economy. The health authorities/ministry of health of Nigeria has not shown any sign of seriousness to deal with the problems associated with 
sickle cell disease, rather it is seen as a personal problem rather than a social problem.

The implication of all these - the financial cost/burden on parents and the trauma that they go through is that it is not just the people living with sickle cell disease that suffer the pain associated with the disease. The parents who are caring for loved ones have been shown to bear the brunt of the disease. What follows from this is that sickle cell disease has produced two sets of sufferers; the people living with the disease and the parents who are caring for loved ones. This is because the financial impoverishment and trauma which the parent/caregivers suffer can result in the parents being physically, mentally and socially ill. The implication of this for health practitioners is that as they treat people living with sickle cell disease, there is need for them to be conscious of the fact that the parent/caregivers may not be objective and cooperative due to trauma and depression. Being conscious of this will help health practitioners to be more sympathetic and patient with parent-caregivers when treating people living with sickle cell disease. For the health authorities/ ministry of health, it implies that healthcare for parents caring for people living with sickle cell disease is of utmost importance and should be given serious attention- the same kind of attention which health of people living with sickle cell disease deserve. As such, health policy on sickle cell disease in Nigeria should include the health of parents who are caring for people living with sickle cell disease. This is a very important issue in the political economy of Nigeria because if the Federal government of Nigeria does not give the healthcare for people living with sickle cell disease and their parents the serious attention that the problem deserves, the trauma and financial burden which parents encounter will continue unabated.

\section{Conclusion}

The paper reviewed the financial burden and trauma experienced by parents of people living with sickle cell disease in Nigeria. It was indicated that parent -caregivers undergo so much financial burden and trauma due to the symptomatic nature of the disease and other socio-economic factors.

The paper concluded that parents of people living with sickle cell disease experience heavy financial burden and trauma and that these experiences are products of the political economy situation in Nigeria and the fact that the disease is life threatening. The problem of financing the treatment of sickle cell disease can be very challenging to many families due to the high cost of drugs and foods. This is especially so in recent times in Nigeria when every item has doubled its prize. Many families are grappling with buying enough food for family members and providing other basic needs. This is particularly significant at this period when the extended family safety net has been weakened by economic recession and urbanization.

The paper recommends the Federal government of Nigeria should put in place a free medical care programme for people living with sickle cell disease and their parents in order to ease the trauma that parents go through in the course of caring for loved ones living with sickle cell disease in Nigeria. Furthermore, public health education officers in the primary healthcare sector should intensify efforts to create awareness on how to prevent sickle cell disease in every nook and cranny of Nigeria. Finally, for health workers to show more understanding and patience, they should be educated by the health authorities on the trauma which parents caring for people living with sickle cell disease are battling with.

\section{References}

1. Ohaeri J U. Shokunbi W A. Psychosocial burdens of sickle cell disease on caregivers in a Nigerian setting. J Natl Med Assoc. J Natl Med Assoc. 2002;94(12):1058-70.

2. Alhassan K. Nigeria ranks first in sickle cell disease burden worldwide with 40 m cases. Leadership Newspaper. 2014.

3. Alege L. The sickle cell disease: Nigeria has the largest cases in the world. Vanguard Newspapers. 2015.

4. World health organization. Sickle disease prevention and control. WHO Country Office, Nigeria. 2014.

5. News Agency of Nigeria. In Nigeria Reps wants FG to subsidies Sickle Cell patients' treatment cost. 2016.

6. Okoegule B. Nigeria ranks first in sickle cell disease burden worldwide with 40 m cases. Leadership Newspaper. 2014.

7. Agbanusi O, Amaechi C, Onyejuzu C, Osuorji C, Chukwuma A, Igwe A. Sickle cell anemia: awareness of sickle cell anemia and its heterozygous state among undergraduate students of university of Nigeria, Enugu campus, Nigeria. Medikka, department of medicine, University, Nsukka, Nigeria. 2007..

8. Aadegoke S. A, Kuteyi E. A. Psychological burden of sickle cell disease on the family, Nigeria. Afr J Prim Health Care Fam Med. 2012;4(1): 380. doi: $10.4102 /$ phcfm.v4i1.380.

9. Afolayan J A, Jolayemi F T. Parental attitude to children with sickle cell disease in selected health facilities in Irepodun Local Government , Kwara State, Nigeria. Kamla-Raj Ethno Med. 2011;5(1):33-40.

10. Tylor E. Primitive culture. London, John Murray, 3rd ed. 1985;1:1-6.

11. Muoghalu CO, Jegede AS. The Role of Cultural Practices and the family in the care for people living with HIV/AIDS among the Igbo of Anambra State, Nigeria. Soc Work Health Care. 2010;49(10):9811006. doi: $10.1080 / 00981389.2010 .518885$.

12. Marsh I. Sociology; Making Sense of Society. Prentice Hall, Pearson Education Ltd, Edinburgh Gate, Harlow. England. 2000.

13. Ritzer G. Sociological Theory. MC Graw-Hill COY. INC. $4^{\text {th }}$ Edition. Singapore. 1996. 